Chirurgia (2017) 112: 244-251

No. 3, May - June

Copyright@ Celsius

http://dx.doi.org/10.21614/chirurgia.112.3.244

\title{
Four Years of Hepatic Transplantation in the Republic of Moldova
}

\author{
Vladimir Hotineanu', Adrian Hotineanu', Serghei Burgoci', Grigore Ivancov², Natalia Taran ${ }^{3}$, Angela Peltec ${ }^{4}$, \\ Dumitru Cazacu², Vitalie Sîrghi
}

${ }^{1} 2^{\text {nd }}$ Surgical Department, "N. Testemițanu" Medicine and Pharmacy State University Public Institution, Chișinău, Republic of Moldova ${ }^{2}$ Clinical Republican Hospital Public Medical-Sanitary Institution, Chișinău, Republic of Moldova

${ }^{3}$ Gastroenterology Scientific Research Laboratory. "N. Testemițanu” Medicine and Pharmacy State University Public Institution, Chișinău, Republic of Moldova

${ }^{4}$ Gastroenterology Department, "N. Testemițanu” Medicine and Pharmacy State University Public Institution, Chișinău, Republic of Moldova

Corresponding author:

Adrian Hotineanu, MD

$2^{\text {nd }}$ Surgical Department, "N. Testemițanu" Medicine and Pharmacy State University Public Institution, Chișinău

Republic of Moldova

E-mail: ahotineanu@hotmail.com

\section{Rezumat}

Patru ani de transplant hepatic în Republica Moldova

Din momentul primului transplant hepatic în Republica Moldova, în 2013, am efectuat 30 de transplante hepatice, primele dintre ele realizate în colaborare cu echipa chirurgicală din România, condusă de Profesorul Irinel Popescu. Deficitul critic de organe cadaverice disponibile ne-au impus să debutăm cu transplant hepatic cu hemificat drept de la donator viu. Intr-o treime de transplante hepatice am utilizat grefa de hemificat drept de la donator viu, iar în $2 / 3$ cazuri grefa de ficat integru prelevat de la donator aflat în moarte cerebrală. Indicațiile pentru intervenție chirugicală în majoritatea cazurilor au fost ciroza hepatică de etiologie virală în faza terminală, trei cazuri de carcinom hepatocelular, câte un caz de ciroză biliară primară, hepatită toxică medicamentoasă şi retransplant hepatic cauzat de tromboza arterei hepatice. 10 grefe cadaverice s-au prelevat de la donatori vârstnici ( $>65$ ani). În perioada postoperatorie precoce au decedat 4 primitori (2 primitori de grefă de la donator viu şi 2 primitori de grefă de la donatori aflați in moarte cerebrală). Cauzele decesului au fost: hemoragie intracerebrală în perioada postoperatorie precoce - 1 , rejet acut al grefei - 1, tromboza arterei hepatice -1 , disfuncție primară a grefei 1. Nu au existat decese în perioada postoperatorie tardivă. Din complicațiile survenite în perioada postoperatorie precoce putem remarca rejet acut al grefei - 2, tromboza arterei hepatice - 1 , 
hemoragie postoperatorie intraabdominală -1 , tromboza arterei hepatice-1, peritonită biliară -1 , disfuncție primară a grefei-1, convulsii -1. Complicațiile în perioada postoperatorie tardivă: peritonită biliară după extragerea drenului din coledoc - 1, "small-for-size" - 2. Experiența acumulată şi utilizarea tehnologiilor moderne ne-au permis să reducem pe parcurs rata mortalității postoperatorii, le fel ca şi rata complicațiilor survenite, pentru a transfera această intervenție chirurgicală din categoria operațiilor de exclusivitate în categoria intervențiilor de zi cu zi.

Cuvinte cheie: transplant hepatic, donator viu, donator aflat în moarte cerebrală, Agenția de transplant

\section{Abstract}

Ever since the first liver transplant in the Republic of Moldova in 2013 we have performed 30 liver transplantations, the first having been performed in collaboration with the surgical team from Romania, led by Professor Irinel Popescu. The serious deficit of available cadaveric organs has forced us to begin with right hemi-liver transplantation from a living donor. In one third of liver transplantations we used right hemi-liver graft from a living donor, and in $2 / 3$ of cases whole liver graft was harvested from brain-dead donors. The indication for surgical intervention in most cases was hepatic cirrhosis of viral aetiology in terminal stages, three cases of hepatocellular carcinoma, and one case for each of primary biliary cirrhosis, drug-induced toxic hepatitis, and liver retransplantation caused by hepatic arterial thrombosis. 10 cadaveric grafts were harvested from elderly donors ( $>$ 65 years). In the early postoperative period, four recipients died (2 live donor graft recipients and 2 graft recipients from donors with brain death). Causes of death were: intracerebral haemorrhage in the early postoperative period - 1 , acute graft rejection - 1 , hepatic artery thrombosis - 1 , primary graft dysfunction - 1 . There were no deaths during the late postoperative period. Of the complications that occurred during the early postoperative period we can highlight acute graft rejection - 2 , hepatic arterial thrombosis - 1, intraabdominal postoperative haemorrhage - 1 , hepatic artery thrombosis -1 , biliary peritonitis - 1 , primary graft dysfunction -1 , seizures -1 . Complications during the postoperative period: biliary peritonitis after choledochal drainage removal - 1, "small-for-size" - 2 . The accumulated experience and the use of modern technologies has allowed us to reduce the postoperative mortality rate, as well as the rate of occurring complications, in order to transfer this surgical intervention from the category of exclusivity operations to the category of daily interventions.

Key words: liver transplantation, living donor, brain-dead donor, transplant agency

\section{Objective}

Hepatic transplantation is indicated for endstage liver disease when the foreseen life expectancy is less than one year, and also in cases where hepatic disease significantly reduces the quality of life and the patient's ability to work, and other methods of alternative treatment are not available (1). Under these conditions, liver transplantation is the only radical measure for the treatment of these patients (2).
Hepatic and gastrointestinal pathologies play an important role in the morbidity of the Republic of Moldova population. The continuing increase in the prevalence of gastrointestinal tract pathology over recent years, the high mortality rate, of which the highest share $(>70 \%)$ covers the working age population, the high level of disability, the great expenses for the treatment of patients, the reduction in quality of life render liver pathology a major medical and social problem in the Republic of Moldova. In the structure of mortality through 
various diseases, in RM digestive pathology is ranked third, outranking cardiovascular diseases and tumours.

WHO statistical data over the past 10 years have shown an alarming situation of chronic diffuse liver disease in the Republic of Moldova, while at the same time our country is considered an endemic area for HVB and HVC viral hepatitis. Prevalence of Chronic Diffuse Liver Disease in 2010 was 2,254.07 per 100,000 population, and the incidence is 264.39 per 100,000 . We can note the fact that in the Republic of Moldova the rate of mortality through gastrointestinal tract diseases far outweighs similar indicators in Europe, based on this parameter our country ranking first in Europe and one of the first in the world. According to WHO data, mortality from gastrointestinal tract pathologies in the US is 20 per 100,000 population, in Germany - 25, in Bulgaria - 30, in the Russian Federation - 45-50, in Romania - 50-60 cases. The mortality rate in the Republic of Moldova for gastrointestinal tract diseases during 1993-1994 increased considerably, up to $115^{-}$ 120 cases per 100,000 population; as of 2011 there is a decline in overall mortality in the country, down to 100.2 cases per 100,000 population, and since $2012-2014$ the rate has remained stable: 101.6-103.1 per 100,000 inhabitants (5).

Among the cases resulting in deaths from GIT diseases, liver pathology plays a leading role, more than $75 \%$ being accounted for by chronic hepatitis and liver cirrhosis. Mortality rates through chronic hepatitis and liver cirrhosis have been steadily rising over the years 2000-2005 - from 83.32 cases / 100,000 population upwards, with stabilization in 2006, and a following downward trend towards 91.5 per 100,000 population in 2009 . In 2010 an increase was again reported, followed by a spectacular fall in 2011, and then an upward trend in 2012. Mortality rates through $\mathrm{CH}$ and $\mathrm{HC}$ within the working age population, including alcoholic aetiology, represent the major part of the index structure $(>70 \%)$ The mortality rate due to cirrhosis of the liver is currently 76.46 per
100,000 population and occupies first place in the world. The onset of liver transplantation has become urgently needed to reduce the mortality rate within this category of patients $(3,4)$.

Until 2013, patients in the Republic of Moldova had not been able to benefit from this treatment method. An important obstacle to the development of transplantation was the lack of organ donors. Among the reasons for this phenomenon are misunderstanding and ignorant negativity towards post-mortem donation in the population, as well as among health workers. Likewise, the insufficient involvement of administrative resources in the organization of unitary coordination for the development of the organ donation system can be incriminated (6). The first step was taken in 2008, when the Law on organ transplantation was passed. In 2010, the Transplantation Agency was opened. The first patient with liver cirrhosis was included on the waiting list in 2012 (7).

However, the beginnings of liver transplantation and its realization took place in February 2013, thanks to the support of the liver transplantation team at the Clinical Institute of Digestive Diseases and Hepatic Transplantation Fundeni, Bucharest, led by Professor Irinel Popescu. Then there were other cases, with grafts from both living donors, and from donors in brain death. The present paper represents a study over the 4-year period of availability of liver transplantation in the Republic of Moldova.

The critical shortage of available organs from donors in brain death has forced us to use liver transplantation from living donors, a method with which we begun the liver transplantation process in the Republic of Moldova. The first liver transplantation was performed on February 22, 2013. The hemi-liver donor was the son of a female patient diagnosed with decompensated viral cirrhosis. The operation was performed with the support of the surgical team from Romania, led by Professor Irinel Popescu.

Since that moment we have accumulated the experience of 30 liver transplantations, including 10 that were performed with the right hemi-liver from living donors. Another 
20 liver grafts were harvested from donors in brain death.

\section{Material and Methods}

During the above-mentioned period, 30 liver transplants were performed. Patients were on the waiting list of the Republic of Moldova Transplantation Agency and were transplanted according to the severity of the liver disease and the degree of urgency (Child Pugh score, MELD). Indications for transplantation were hepatic cirrhosis of viral aetiology and cellular hepatocarcinoma. The following types of hepatic transplantation were performed, all on adult patients: whole liver from cerebral death donor -20 recipients, including a retransplantation, and live donor liver transplantation, using the right liver lobe -10 recipients. The study included 10 live donors, mean age $34.81 \pm 11.59$ years. Hepatic steatosis (15-20\%) was confirmed by preoperative liver biopsy puncture in 6 (60\%) donors. The average age of recipients ranged from 27 to 61 years. The MELD score varied between 14-19 points. Among the cases of liver transplantation, we mention two special cases: one of group incompatibility, and the second of acute liver failure developed as a result of Budd-Chiari syndrome. The most common indications were: hepatic cirrhosis of viral aetiology - caused by liver virus C - 4 cases, liver virus B - 4 cases, liver virus D - 14 cases, 4 cases of hepatocarcinoma, and one
Table 1. Aetiology of patients requiring liver transplantation

\begin{tabular}{lcc}
\hline & $\mathbf{n}$ & $\%$ \\
\hline HVB + HVD & 14 & 46.6 \\
\hline HVB & 4 & 13.3 \\
\hline HVC & 4 & 13.3 \\
\hline HVC + HCC & 2 & 6.6 \\
\hline HVB + HVD + HCC & 2 & 6.6 \\
\hline HVB + HVC & 1 & 3.3 \\
\hline Budd-Chiari Syndrome & 1 & 3.3 \\
\hline Primary sclerosing cholangitis & 1 & 3.3 \\
\hline Retransplantation & 1 & 3.3 \\
\hline
\end{tabular}

case of HVB + HVC, Budd-Chiari syndrome, primary sclerosing cholangitis, retransplantation (Table 1). Retransplantation was performed with whole graft from a cerebral death donor to a recipient who underwent liver transplantation from a living donor 5 days prior, which was however complicated by hepatic artery thrombosis.

All harvesting centres are located in Chiæinãu, within a radius of $20 \mathrm{~km}$ from the transplantation clinic, which allowed the achievement of a short time of cold ischemia, of 3-4 hours. All of the surgical techniques used in liver harvesting from donors in brain death, of hemi-liver harvesting from live donors, as well as graft implantation techniques correspond to the techniques used at Fundeni Hepatic Transplantation Centre $(8,9)$.

Hepatectomy in recipients was performed with the conservation of the inferior vena cava in all cases (Figs. 1, 2).

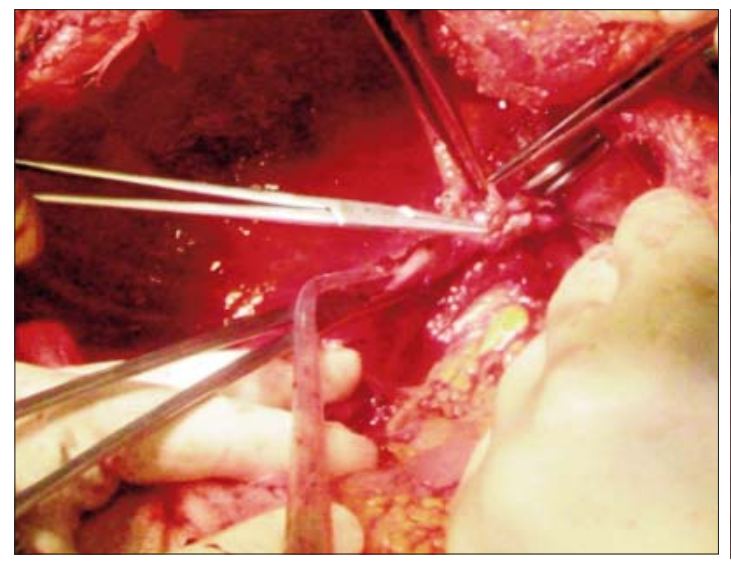

Figure 1. Hepatectomy in the recipient

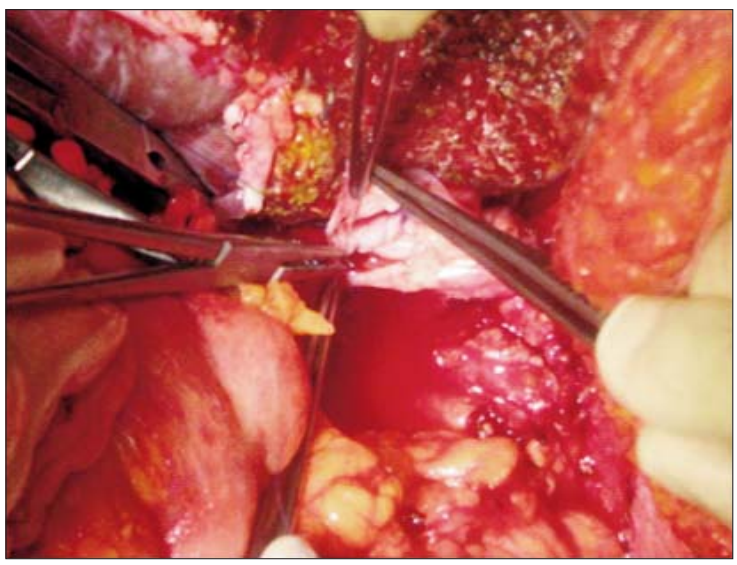

Figure 2. Right hepatic vein - inferior vena cava anastomosis in the recipient 


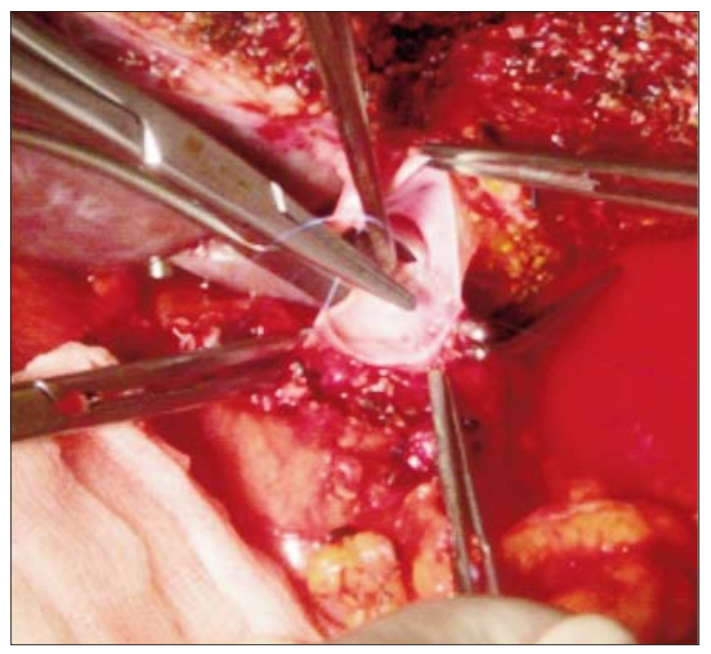

Figure 3. Portal anastomosis

Transplantation from a living donor: we performed liver transsection in the donor with the CUSA dissector. In all cases, the right hepatic vein from the donor was anastomosed in terminal-lateral position with the vena cava, and in termino-terminal position with the vena porta (Fig. 3). In 2 cases, the right inferior hepatic vein was anastomosed with the inferior vena cava. The median hepatic vein was reconstructed with iliac artery graft in 3 cases and implanted in the lower vena cava. The right hepatic artery of the graft was anastomosed with the proper hepatic artery in termino-terminal position by means of the microscope (Fig. 4). Choledochal reconstruction was performed by implanting the bile duct into the jejunal loop by $\mathrm{Y}$ a la Roux technique (Fig. 5). In 8 cases two bile ducts were determined (Table 2).

Liver transplantation with whole liver from a brain-dead donor: in all cases cavoplasty was performed by triangulation with latero-lateral cavo-caval anastomosis with total clamping of

Table 2. Particularities of the reconstructive stage in hepatic transplantation from a living donor

\begin{tabular}{lc}
\hline Right inferior hepatic vein & 2 \\
\hline Median hepatic vein reconstruction & 2 \\
\hline 2 bile ducts & 8 \\
\hline Portal vein thrombosis & 1 \\
\hline
\end{tabular}

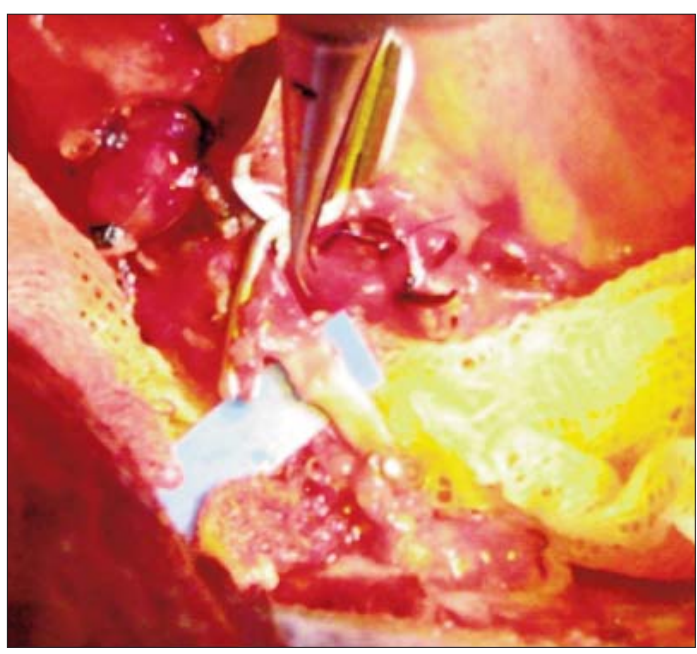

Figure 4. Arterial anastomosis

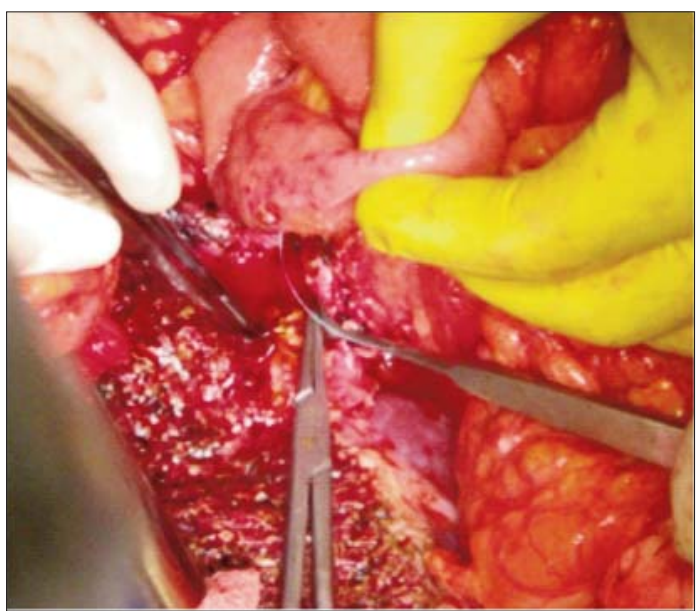

Figure 5. Biliodigestive reconstruction

the inferior vena cava. Portal reconstruction was performed by termino-terminal porto-portal anastomosis, and in 2 cases thrombectomy for portal vein thrombosis was necessary. The arterial anastomosis was performed via the patch obtained through the junction of the common hepatic artery and the gastroduodenal artery, and in 3 cases it was implanted in the infrarenal aorta. Biliary reconstruction was performed in termino-terminal position, in 2 cases the choledochal graft being implanted in the jejunal loop by Y a la Roux technique.

The critical shortage of organ donors in brain death has forced us to use organs collected from elderly donors (55-78 years) on a 
large scale. Recently, there are more and more discussions in the literature concerning the use of cadaveric grafts from elderly donors. Such issues arise due of the disproportion between the number of patients on the waiting list and that of donors who are in brain death. This is why many transplant centres have increased the upper age limit from the previous 50 years limit to 70 years. Liver transplantation with whole liver from an elderly donor was performed in 10 cases. Hospital stay ranged between 16 and 42 days. In one case, the recipient died due to acute graft rejection. The other 9 recipients had no complications within 3 years of follow-up. Although graft quality from elderly donors is suboptimal compared to young donors, primary graft dysfunction did not occur. On the other hand, long-term survival cannot be calculated due to the short-term research on recipients. As preliminary results we can observe that whole liver hepatic transplantation from elderly donors in brain death is a relatively safe method. However, elderly donors and appropriate recipients should be carefully selected before transplantation.

Immunosuppression was obtained in 2 stages:

1. Anhepatic phase induction with steroids or monoclonal antibodies (baziliximab);

2. Recipient maintenance by combined treatment: calcineurin inhibitor (tacrolimus), antimetabolite (mycophenolate mofetil), steroids (methylprednisolone).

During the immediate postoperative period, vital graft functions were monitored and recorded, as well as the plasma level of the calcineurin inhibitor $(12.0-10.0-8.0 \mathrm{ng} / \mathrm{ml})$. Prophylaxis of viral infection was performed: for hepatitis B virus, CMV infection, Toxoplasma. CMV infection prophylaxis was performed according to the established protocol, as well as to the international guidelines (over the first 3 months, in case of presence of CMV positive IgMs during graft evaluation). Prophylaxis of viral hepatitis B recurrence was performed by administration of Ig and nucleoside analogues (lamivudine).

\section{Results}

There were no complications in donors.
Lethality during early postoperative period - 4 cases $(13.3 \%)$. There were no late postoperative period deaths. The first patient died 3 days postoperatively through intracerebral haemorrhage, the second patient died 5 days postoperatively due to acute rejection of the graft. These two cases were from donors in brain death, while the following two were patients receiving a hemi-liver graft from living donors. In the third case death occurred 10 days postoperatively, caused by hepatic artery thrombosis, and in the fourth case death occurred on the 12 th postoperative day through primary graft dysfunction, caused by arterial hypoperfusion of the graft. Immediate postoperative survival was $86.7 \%$, graft survival at 1 year was $83.4 \%$. Early complications (in the first 30 days postoperatively) were diagnosed in 7 patients $(25.9 \%)$. The most common complications were vascular: 2 cases of hepatic artery thrombosis, one resolved by hepatic retransplantation on postoperative day 5, 1 case of intraabdominal haemorrhage, resolved by reintervention, 2 cases of acute rejection of the graft - one treated by pulse therapy, followed by infectious complications: abdominal (peritonitis) - 1 case, and cutaneous / subcutaneous (1 case).

Among the most frequent postoperative general complications are renal complications - 4 cases, neurological - 2 cases, respiratory 11 cases, treatment being specific to aetiology. "Small-for-size" syndrome, a specific complication of hepatic transplantation from a living donor, was recorded in 2 cases, both of which were conservatively treated.

Late complications were reported in 11 patients. Complications during late postoperative period included: the structure of the hepatico-jejunal anastomosis at 16 months - 1 case, treated by laparotomy and anastomosis plasty, and a second case at 13 months, resolved through endoscopic stenosis, as well as one case of biliary peritonitis at 7 months, after removal of the choledochal drainage (Table 3).

Recurrence of the initial viral infection was recorded in 9 patients, including hepatitis $\mathrm{C}$ virus infection (4 patients) and hepatitis $B$ 
Table 3. Complications during the late postoperative period

\begin{tabular}{lcl}
\hline & No. of cases & Treatment \\
\hline Hepatic artery thrombosis & 2 & $\begin{array}{l}\text { 1. Relaparotomy } \\
\text { 2. Death }\end{array}$ \\
\hline Intraabdominal postoperative haemorrhage & 1 & Relaparotomy \\
\hline Intracerebral postoperative haemorrhage & 1 & Death \\
\hline Biliary fistula, Biliary peritonitis & 1 & Relaparotomy \\
\hline Wound suppuration & 1 & Aseptic dressing \\
\hline Acute graft rejection & 2 & 1. Pulse therapy \\
& & 2. Death \\
\hline Primary graft dysfunction & 1 & Death \\
\hline Small for Size & 2 & Conservatively \\
\hline Renal & 4 & Conservatively \\
\hline Respiratory & 11 & Conservatively \\
\hline Neurological & 2 & Conservatively \\
\hline
\end{tabular}

virus infection ( 5 patients). It should be noted that antiviral treatment was initiated in 3 patients with HVC, in 1 patient combined antiviral treatment (Exviera / Viekirax) for 24 weeks, with a reduction in immunosuppression being necessary, and in the other 2 patients antiviral treatment with Sofosbuvir and Ledipasvir (Twinvir). Patients with recurrence of viral infection $B$ were administered treatment with Tenofovir associated with Ig B. Among the cases of viral infections in the postoperative period, there is evidence of reactivation of CMV infection (3 cases), and 1 case of CMV first infection, all resolved by treatment with Valganciclovir.

\section{Discussions}

However, the number of postoperative complications, in-hospital mortality and the longterm survival of patients in different countries vary greatly. Thus, according to the European Liver Transplant Registry (ELTR), mortality after surgery depends on a number of factors: "donor", "recipient", logistical and organizational factors, based on the level of specialized medical care in the country. Equally important are the qualifications and experience of specialists and of the transplant centre.

The number of recipients on the waiting list, the long waiting period, and the insufficient number of brain-dead donors cause increased mortality among these patients. It is worth mentioning that the basic indication for liver transplantation is considered to be terminal liver disease, but considering the acceptance of marginal donors, selecting recipients from the waiting list is difficult, and careful selection based on the absence of multi-systemic complications of the disease among them is necessary. According to our study, most liver transplantations performed are due to HVD liver cirrhosis (14), due to the increased incidence of cirrhosis of viral aetiology B and D. Because of organ shortage, more than $75 \%$ marginal donors were accepted for liver transplantation, including 2 with positive anti $\mathrm{Hb}$ Cor sum. The lack of organs and the long waiting period made it possible to carry out live donor transplantation (8), thanks to the HT team support from the Fundeni Clinical Institute (Romania) led by Professor Irinel Popescu. According to the institutional protocol, waiting list recipients, as well as transplanted patients, are under the attention of the HT team, being monitored continuously.

\section{Conclusions}

The launch of the liver transplantation program in the Republic of Moldova was possible due to the remarkable success of the 
Ministry of Health in terms of the organization and functioning of the Transplantation Agency, by approving the Regulations on the organization and functioning of the independent commission for inclusion working along with the $\mathrm{MH}$, and the authorization criteria for carrying out harvesting and transplantation activities, as well as due to the support of the liver transplantation team from the Clinical Institute of Digestive Diseases and HT Fundeni (Romania). The liver transplantation program needs to be further developed by rigorously selecting recipients and donors, as well as by raising awareness of organ donation in the population. At this stage, liver transplantation in the Republic of Moldova can be considered a relatively safe procedure for the treatment of terminal stage liver cirrhosis. However, the complications that have occurred are a major problem that forces us to constantly improve the knowledge and understanding of surgical techniques, postoperative management, and immunosuppressive therapy.

\section{References}

1. EASL Clinical Practice Guidelines: Liver transplantation. J Hepatol. 2016;64(2):433-85. doi: 10.1016/j.jhep.2015.10.006. Epub 2015 Nov 17.

2. Cholongitas E, Marelli L, Shusang V, Senzolo M, Rolles K, Patch D, et al. A systematic review of the performance of the model for endstage liver disease (MELD) in the setting of liver transplantation. Liver Transpl. 2006;12(7):1049-61.

3. Iu. Lupasco. Aspecte de diagnostic al hepatitelor cronice și bolilor cronice difuze ale ficatului determinate prin examenul profilactic al populației sănătoase. Revista Sănătatea publică, economie și management în medicină. 2014; 56(5):49-55.

4. Lupașco lu. Diagnosticul hepatitelor cronice și altor forme de boli difuze ale ficatului, determinate prin examen profilactic al populației sănătoase. Revista Sănătatea publică, economie și management în medicină. 2014;56(5):56-63.

5. Dumbrava VT, Proca N, Lupașco I, Harea G. Patologia hepatică și cea gastrointestinală - probleme sociale actuale în Republica Moldova. Revista științifico-practică „Sănătate publică, economie și Management în Medicină”. 2013; 50(5):7-12.

6. Peltec A, Hotineanu A, Hotineanu V, Brașoveanu V, Dumbrava VT, et al. Steatoza hepatica nonalcoolică și transplantul hepatic: contoverse, rezultate și progrese. În: Sănătate publică, economie și management în medicină.Chișinău. 2014;56(5):149-52.

7. Hotineanu V, Peltec A, Castells L, Ivancov G, Taran N, Moraru E, et al. Transplant hepatic: Spania vs Republica Moldova - schimb de experiență. Buletinul Academiei de științe a Moldovei. Chișinău. 2015;46(1):179-84.

8. Popescu I. Chirurgia ficatului. București: Ed. Universitară „Carol Davila"; 2004.

9. Popescu I. Transplantul hepatic. București: Ed. Academiei Române; 2011. 